\title{
Overexpression of the insulin-like growth factor I receptor in human pheochromocytomas
}

\author{
Christian Fottner, Timo Minnemann, Sarah Kalmbach and Matthias M Weber \\ Schwerpunkt Endokrinologie und Stoffwechselerkrankungen, I Medizinische Klinik und Poliklinik der Johannes Gutenberg Universität Mainz, Langenbeckstrasse 1, \\ 55131 Mainz, Germany \\ (Requests for offprints should be addressed to M M Weber; Email: MMWeber@ uni-mainz.de)
}

\begin{abstract}
In order to determine the role of the IGF-I receptor (IGF-IR) in human pheochromocytomas we have compared the expression of the IGF-IR in normal tissues and in pheochromocytomas with regard to the IGF-IR mRNA levels and ligand binding. By semiquantitative reverse transcription polymerase chain reaction (RT-PCR), the mRNA of the IGF-IR could be detected in all samples of normal adrenomedullary cells $(n=13)$ and pheochromocytomas $(n=16)$. However, pheochromocytomas exhibited 2.8-fold higher mean IGF-IR mRNA levels than normal adrenomedullary cells

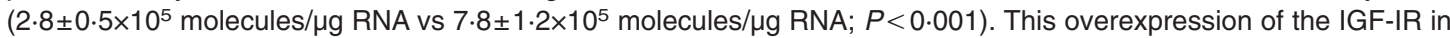
pheochromocytomas could be confirmed at the protein level by binding studies. Radioligand assays and Scatchard analysis revealed a single class of high affinity IGF-IR binding sites with a similar dissociation constant $\left(K_{\mathrm{d}}\right.$ : $0.32 \pm 0.1 \mathrm{nmol} / \mathrm{l}$ vs $0.22 \pm 0.08 \mathrm{nmol} / \mathrm{l})$ for both normal adrenomedullary cells and pheochromocytomas. However, specific 125 -labeled IGF-I binding and the calculated receptor concentration were significantly elevated in pheochromocytomas as compared with normal adrenomedullary cells $(58 \cdot 3 \pm 5 \mathrm{vs} 24 \cdot 3 \pm 12 \mathrm{nmol} / \mathrm{kg}$ protein; $P<0.05)$. In summary, our results demonstrate significant overexpression of the IGF-IR in human pheochromocytomas. This suggests a possible role of the IGF system in the pathogenesis of adrenal neoplasia and thus IGF-IR may be a target for future therapeutic approaches.
\end{abstract}

Journal of Molecular Endocrinology (2006) 36, 279-287

\section{Introduction}

Previous studies by our own group and others have shown a critical role for the insulin-like growth factor (IGF) system in either normal adrenocortical cells or adrenocortical tumors (Weber et al. 1997, Boulle et al. 1998, Fottner et al. 1998, 2001). In malignant adrenocortical carcinomas, overexpression of IGF peptides (mainly IGF-II), receptors (IGF-IR) and binding proteins (IGFBP-2) has been observed. In contrast, expression of IGF-I peptides and receptors appears to be unaltered in adrenocortical hyperplasia and adenomas.

The IGF system has also been shown to play a potent regulatory role in cell proliferation and maintenance of sympathetic ganglia and adrenal medulla. In adult adrenal medulla and sympathetic ganglia, gene expression of IGF-I and IGF-II and their receptors was proven at the mRNA level (Haselbacher et al. 1987, Gelato \& Vassalotti 1990, Ilvesmäki et al. 1993). IGFs have been shown to promote chromaffin cell survival and proliferation in vivo (Frödin \& Gammeltoft 1994); moreover IGF-I enhances catecholamine synthesis (Hwang \& Choi 1996) and secretion (Dahmer et al. 1990) in these cells.
Interestingly, alterations in the IGF system also seem to play an important role in tumors originating from the adrenal medulla or sympathetic ganglia, like pheochromocytomas or neuroblastomas. Overexpresion of the IGF-I receptor in neuroblastoma cells results in resistance to apoptosis leading to unregulated growth (Singleton et al. 1996). IGF-II (Sullivan et al. 1995) and IGFBP-2 (Menouny et al. 1997) are widely expressed in human neuroblastomas possibly enhancing and/or modulating IGF-I receptor activation. Overall, alterations in the IGF system have been shown to modulate neuroblastoma growth in vitro, thus underlining its importance in the growth-maintenance of these highly malignant tumors (reviewed in Zumkeller \& Schwab 1999).

Overexpression of IGF-II mRNA and peptide has been described in human pheochromocytomas (Haselbacher et al. 1987, Gelato \& Vassalotti 1990). However, no information about the abundance of the IGF-I receptor in human pheochromocytomas compared with normal adrenomedullary tissue is available to date. In order to evaluate whether the IGF-IR is overexpressed in human pheochromocytomas, we therefore investigated the expression of the IGF-IR in normal adult adrenomedullary tissue and in pheochro- 
mocytomas with regard to mRNA levels and ligand binding in vivo.

\section{Materials and methods}

\section{Materials and sample collection}

Recombinant human IGF-I was purchased from Boehringer (Mannheim, Germany), (3-[ $\left[{ }^{125} \Gamma\right]$ iodotyrosyl) IGF-I (human recombinant, specific activity 2000 $\mathrm{Ci} / \mathrm{mmol}$ ) was purchased from Amersham Buchler GmbH \& CoKG (Braunschweig, Germany). Molecular biology reagents for reverse transcription (RT)-PCR were obtained from Promega (San Diego, CA, USA) and Gibco BRL (Eggenheim, Germany).

According to the guidelines of the ethics committee of the Ludwig-Maximilians-University of Munich, normal adrenal tissue was obtained from patients undergoing surgical treatment for renal neoplasia with concomitant ipsilateral adrenalectomy. Immediately after surgical removal, the tissue was dissected by the pathologist and a sample of fresh, non-necrotic adrenal tissue was provided. All adrenal glands were found to be normal after morphological and histopathological examination. Due to the large amount of protein necessary for the binding studies, tissue from only five adrenal glands provided enough material for membrane preparation and consecutive binding assays. If only small parts of the intact adrenal gland were available after pathological analysis, the tissue was used for mRNA isolation. Pheochromocytomas were obtained from patients undergoing surgical treatment of adrenal neoplasia. All patients gave written informed consent. Immediately after surgical removal, samples of normal adrenal tissue and of pheochromocytomas were dissected by the pathologist and a sample of fresh non-necrotic representative adrenal tissue was provided. All adrenal glands were found to be normal after morphological and histopathological examination. For the tumor samples, necrotic and ulcerative portions were removed when necessary and the presence of at least $90 \%$ tumor cells was verified histologically. For the preparation of adrenomedullary tissue samples, adrenal glands were freed from the periadrenal fat tissue, incised longitudinally and the adrenal medulla was separated from the cortex under a dissecting microscope. For RNA extraction and membrane preparation, tissue samples were snap frozen in liquid nitrogen and stored at $-70{ }^{\circ} \mathrm{C}$ until further analysis.

The mean age of the pheochromocytoma patients at the time of surgery was 43.5 years and the female/male ratio was $1 \cdot 2: 1$. One of the pheochromocytomas was classified as malignant due to the presence of distant metastases (lung and local intestinal lymph-node metastases). The mean tumor size was $3 \cdot 4 \pm 1 \cdot 2 \mathrm{~cm}$. Two of the 17 histologically verified pheochromocyto- mas occurred as part of multiple endocrine neoplasia type 2 (MEN 2) and three occurred as part of von Hippel-Lindau disease. The mean age of the patients undergoing adrenalectomy due to renal neoplasia was $64 \cdot 3$ years and the female/male ratio was $1: 1 \cdot 4$.

\section{RT-PCR}

For measurement of IGF-IR levels in 13 normal adrenal glands and 16 pheochromocytomas, a commercially available competitive quantitative RT-PCR method (Clontech Laboratories, Palo Alto, GA, USA) was used, as previously described in detail (Weber et al. 2002). The MIMIC PGR technique utilizes an exogenous internal standard (MIMIC), which competes for the same primers as the target IGF-I receptor DNA. With knowledge of the amount of MIMIC DNA added in serial dilutions to the amplification reactions, the amount of the target template could be determined, and thus the amount of initial IGF-IR. The competitive internal standard, which contains the identical primer binding sites used to amplify the IGF-IR DNA was generated by amplifying a BamH1/EcoR1 fragment of v-erB with two composite primers. In these composite primers (40-mer), the first 20 nucleotides are complementary to IGF-II or the IGF-IR and the following 20 nucleotides are complementary to v-erB. The internal standard was synthesized, purified and quantified by spectophotometry as described by the manufacturer (Clontech Laboratories). Amplification of the competitive internal standard generated a $288 \mathrm{bp}$ fragment. The primers used to amplify the human IGF-IR and the internal standard respectively were: sense 5'ACAGAG AACCCCAAGACTGAGG3', antisense: 5'TGATGTT GTAGGTGTCTGGGGC3', corresponding to nucleotides 2095-2116 (exon 10) and 2341-2320 (exon 11) of the human IGF-IR cDNA sequence (Ullrich et al. 1986). Amplification of the target DNA with these intronoverlapping primers yielded one specific $247 \mathrm{bp}$ fragment of the IGF-IR, thereby excluding amplification of contaminating DNA. The PCR products obtained were confirmed by sequencing. In pilot experiments, the exponential phase of the amplification was determined for the target DNA and the internal standard. Subsequently, a cycle number that was in the middle of the linear amplification range (21-27 cycles) was chosen. In the system used, the efficiencies of amplification of target cDNA and competitive internal standard DNA were equal (Gilliland et al. 1990, Alms et al. 1996, Becker-Andre et al. 1989, Kutoh et al. 1998, Zhang et al. 1998).

For RNA extraction, $50 \mathrm{mg}$ tissue specimens were incubated with $1 \mathrm{ml}$ cell lysis buffer (Trizol, Gibco, Grand Island, NY, USA) for 5 min, then total cellular RNA was isolated using the acid-guanidinium isothiocyanate phenol-chloroform extraction method as 
described by Chomczynski \& Sacchi (1987). The assessment of RNA integrity was evaluated by inspection of the $28 \mathrm{~S}$ and $18 \mathrm{~S}$ ribosomal RNA bands using gel electrophoresis, and the concentration and purity of the RNA were further determined by ultraviolet spectrophotometry; RNA was stored at $-70{ }^{\circ} \mathrm{C}$ until analyzed. For reverse transcription of extracted RNA to cDNA, $1 \cdot 0 \mu \mathrm{g}$ total RNA template was incubated for $60 \mathrm{~min}$ at $37^{\circ} \mathrm{C}$ in $20 \mu \mathrm{l}$ reaction volume containing $1 \times 1$ st strand buffer (50 mM Tris/HCl, $75 \mathrm{mM} \mathrm{KCl,} 3 \mathrm{mM} \mathrm{MgCl}_{2}$ ), $0.5 \mathrm{mM}$ of each deoxynucleotide, $1.8 \mu \mathrm{g}$ random primer, $10 \mathrm{mM}$ dithiothreitol (DTT), $20 \mathrm{U}$ ribonuclease inhibitor RNasin $(1.0 \mathrm{U} / \mu \mathrm{l})$, and $240 \mathrm{U}$ Moloney murine leukemia virus reverse transcriptase $(12 \mathrm{U} / \mu \mathrm{l})$. The reaction was stopped by incubating at $95^{\circ} \mathrm{C}$ for $5 \mathrm{~min}$, and samples were placed on ice or stored at $-20{ }^{\circ} \mathrm{C}$ for further analysis. Subsequently, PCRs were performed in a thermal cycler (Gene Amp PCR System 2400, Perkin-Elmer, Weiterstadt, Germany and icycler, BioRad, Munich, Germany): $2 \mu \mathrm{l}$ RT product and internal MIMIC standard in serial dilution were amplified in a volume of $50 \mu \mathrm{l}$, containing $1 \times$ PCR buffer $(10 \mathrm{mM}$ Tris-HCl, pH $9 \cdot 0,50 \mathrm{mM} \mathrm{KCl})$, $1.0 \mathrm{mM} \quad \mathrm{MgCl}_{2}, 200 \mu \mathrm{M}$ each deoxynucleotide, $0.6 \mathrm{pmol} / \mu \mathrm{l}$ each primer, and $0.06 \mathrm{U} / \mu \mathrm{l}$ Taq DNA polymerase. The first denaturation step $\left(95^{\circ} \mathrm{C}\right.$ for $\left.6 \mathrm{~min}\right)$ was followed by 29 cycles with a 1 min denaturing step at $95{ }^{\circ} \mathrm{C}$, a 1 min annealing step, starting at $70{ }^{\circ} \mathrm{C}$ and decreasing by $0.5^{\circ} \mathrm{C}$ with each cycle to a minimum of $65^{\circ} \mathrm{C}$, and a 1.5 min elongation step at $72{ }^{\circ} \mathrm{C}$. As a final extension step, the reaction was heated to $72{ }^{\circ} \mathrm{C}$ for $6 \mathrm{~min}$ and then cooled. PGR products were electrophoresed on a 1.5 agarose-gel with a $1 \mathrm{~Kb}$ DNA ladder followed by ethidium-bromide staining. The stained gel was analyzed with a computerized scanner and image analyzing software (NIH Image, version 1·61, National Institute of Health, Bethesda, MD, USA). Routinely, negative controls without input RNA or with omitted RT-step were included. For quantification of the target mRNA levels, equal amounts of target cDNA were amplified with different dilutions of known amounts of MIMIC DNA. After RT-PCR, the ratios of MIMIC to target band intensity were determined, and the concentration of a 1:1 MIMIC/target ratio was calculated as described (Kutoh et al. 1998). For each sample, an initial estimate of IGF-IR mRNA was performed with a single dose of internal standard DNA, followed by a narrow titration of internal standards around this estimated value, according to the method of Alms et al. (1996). Results were expressed as number of molecules per $\mu \mathrm{g}$ total RNA. The RNA of each sample was reverse transcribed and analyzed by RT-PCR in duplicate in two separate experiments. Using this method, the intra-assay coefficient of variation for IGF-IR mRNA quantification was $3 \%$, and the interassay coefficient of variation was $11 \%$.

\section{IGF-I binding studies}

${ }^{125}$ I-IGF-I binding studies were performed with membrane preparations of 5 normal adrenomedullary tissue samples and 17 pheochromocytomas as previously described (Weber et al. 1997). Briefly, tissue samples were homogenized mechanically in homogenization buffer $(0.25 \mathrm{M}$ sucrose, $0.25 \mathrm{mg} / \mathrm{l}$ antipain and $100 \mathrm{mg} / \mathrm{l}$ phenylmethyl sulfonyl fluoride (PMSF) and centrifuged at $600 \mathrm{~g}$ for $10 \mathrm{~min}$. The supernatant was centrifuged at $10000 \boldsymbol{g}$ for $30 \mathrm{~min}$, adjusted to a final concentration of $0.1 \mathrm{~mol} / \mathrm{l} \mathrm{NaCl}$ and $0.2 \times 10^{-3} \mathrm{~mol} / \mathrm{l} \mathrm{Mg}_{2} \mathrm{SO}_{4}$, centrifuged twice at $100000 \mathrm{~g}$ for $90 \mathrm{~min}$ and resuspended in membrane buffer $(50 \mathrm{mM}$ Tris- $\mathrm{HCl}, \mathrm{pH}$ $7 \cdot 4 ; 0.25 \mathrm{mg} / \mathrm{l}$ antipain and $100 \mathrm{mg} / \mathrm{l} \mathrm{PMSF}$ ). Aliquots of $80 \mu \mathrm{g}$ membrane protein were incubated for $3 \mathrm{~h}$ at room temperature together with ${ }^{125}$ I-IGF-I (20 000 c.p.m.) and increasing concentrations of unlabeled IGF-I in $400 \mu \mathrm{l}$ binding buffer (Medium 199 containing 0.2\% bovine serum albumin, $150 \mathrm{mM} \mathrm{NaCl}$ and $1.2 \mathrm{mM}$ $\left.\mathrm{MgSO}_{4}\right)$. Membrane bound radioactivity was measured and receptor kinetics were calculated by Scatchard analysis (Scatchard 1949) using a standard software program (Ligand, NICHHD, NIH, Bethesda, MD, USA).

\section{Statistical analysis}

All data are expressed as means \pm S.E.M. Comparative data were analyzed by multivariate analysis and paired $t$-test with significance defined as $P<0.05$, unless otherwise stated.

\section{Results}

\section{IGF-I receptor mRNA expression in human pheochromocytomas}

The expression of IGF-IR mRNA in human pheochromocytomas was compared with normal adrenal medulla by quantitative RT-PCR of tissue samples from 16 patients with pheochromocytomas and from 13 normal adrenal glands. Amplification of cDNA with primers located in exons 10 and 11 yielded one specific PCR product of $247 \mathrm{bp}$ (Fig. 1). Sequence analysis showed that these products were identical with the cDNA sequence of the human IGF-IR (data not shown). No products were detected when the RT reaction or the input RNA were omitted. Furthermore, the same size and intensity of the amplification product was observed when the RNA was treated with DNase prior to RT-PCR, excluding possible amplification of contaminating DNA. Expression of the human IGF-IR gene was detected in the tissues of all patients. In the normal adrenal medulla, IGF-IR was expressed at $2751 \pm$ $541 \times 10^{3}$ molecules/ $\mu \mathrm{g}$ RNA, while significantly higher 
A standard-dilution

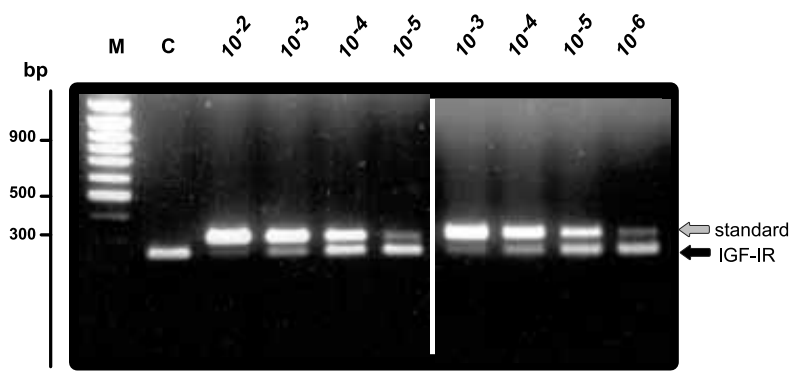

pheochromocytoma adrenal medulla

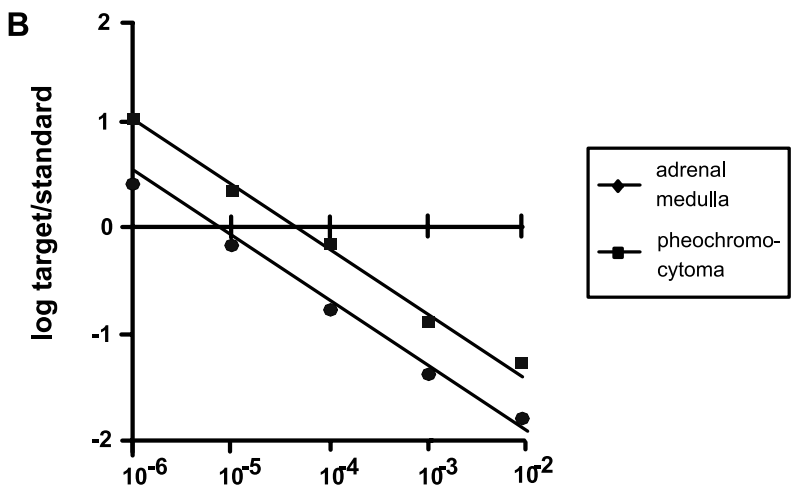

standard-dilution

Figure 1 Representative result of the RT-PCR analysis of normal adrenomedullary tissue and a human pheochromocytoma. (A) Ethidium bromide staining of amplification products separated on an agarose gel. One microgram total RNA was reverse transcribed and amplified together with serial dilutions of internal control DNA using the same IGF-IR primers. The figure shows a typical titration experiment performed using $10^{-2}$ - to $10^{-6}$-fold dilutions of the internal standard (100 amol/l) and fixed amounts of the target cDNA. M, marker; C, control. (B) Representative linear regression analysis of the internal standard titration curve obtained with the DNA from a pheochromocytoma $(\square)$ and normal adrenomedullary tissue $(\bullet)$. The values on the ordinate are the log of the internal standard/target cDNA ratio. The values on the abscissa are dilutions of the internal standard on a log scale. The titration point corresponds to the intersection with the 0 axis.

levels were observed in tumor samples, with a mean expression of $7772 \pm 1203 \times 10^{3}$ molecules/ $\mu \mathrm{g}$ RNA $(P<0 \cdot 001)$. Figure 1 shows a representative result of the quantitative RT-PCR analysis from two samples of normal adrenomedullary and pheochromocytoma tissue. When the IGF-IR mRNA levels of pheochromocytoma tissue samples were analyzed (Fig. 2), in contrast to normal adrenal glands, a wide heterogeneity in IGF-IR mRNA levels was observed (2303-20 520 $\times 10^{3}$ molecules/ug RNA) (Table 1). However, IGF-IR mRNA levels of pheochromocytoma tissue samples showed 2.83-fold higher IGF-IR levels than normal

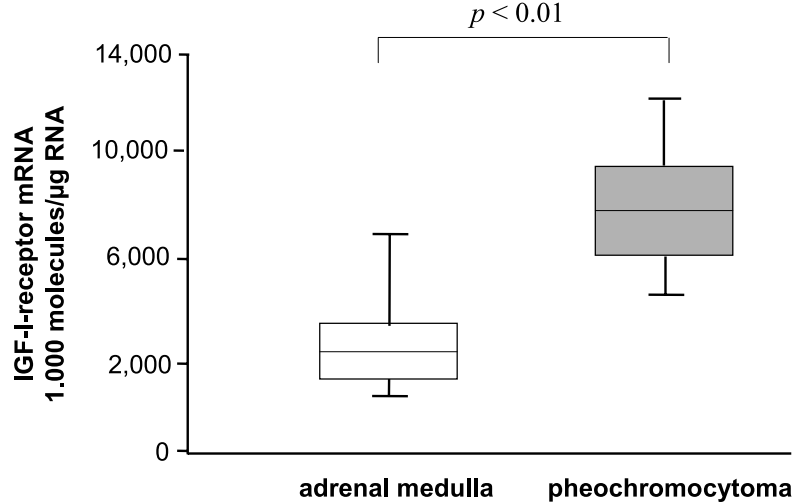

Figure 2 Mean IGF-IR expression 1000 molecules/ug RNA in human pheochromocytomas (shaded bar; $n=16$ ) and normal adrenomedullary tissue (open bar; $n=13$ ).

adrenomedullary tissue $(P<0 \cdot 01)$. Seventy-five percent of human pheochromocytomas showed a more than 2-fold overexpression of the IGF-IR as compared with normal adrenal medulla. IGF-IR expression was unrelated to tumor size, age, sex and catecholamine secretion. However, the highest IGF-IR mRNA level of all investigated tissue specimens was seen in the only malignant pheochromocytoma investigated in this series.

\section{IGF binding to normal adrenomedullary and pheochromocytoma tissue}

Binding kinetics of ${ }^{125}$ I-IGF-I to membranes from five normal adrenal medullas and 17 pheochromocytomas was investigated. The mean specific binding of ${ }^{125}$ I-IGF-I to membranes from normal human adrenal medulla was $3 \cdot 6 \pm 0.9 \%$. ${ }^{125}$ I-IGF-I binding could be effectively displaced by unlabeled IGF-I with a $50 \%$ displacement $\left(\mathrm{ED}_{50}\right)$ at $6 \cdot 1 \pm 2 \cdot 0 \mathrm{ng} / \mathrm{ml}$. In contrast, significantly higher concentrations of IGF-II were necessary for a 50\% displacement, and insulin was effective only at micromolar concentrations (data not shown). Scatchard analysis revealed a single-class of high-affinity binding sites with a $K_{\mathrm{d}}$ of $0 \cdot 32 \pm 0 \cdot 1 \mathrm{nmol} / \mathrm{l}$ and a receptor concentration of $2.43 \pm 1.2 \mathrm{nmol} / \mathrm{kg}$ protein (Fig. 3). In comparison with normal adrenomedullary tissue, membrane preparations from the pheochromocytoma tissues showed a significantly higher specific ${ }^{125}$ I-IGF-I binding of $7 \cdot 0 \pm 1 \cdot 1 \%$, as well as an elevated mean IGF-IR concentration of $5 \cdot 8 \pm 0 \cdot 5 \mathrm{nmol} / \mathrm{kg}$ protein $(P<0 \cdot 05)$. The mean IGF-IR concentration was about $2 \cdot 4$-fold higher in pheochromocytomas as compared with normal adrenomedullary tissue. However, IGF-I was equally potent in displacing the labeled ligand from pheochromocytoma membranes $\left(\mathrm{ED}_{50} \quad 5 \cdot 6 \pm 1 \cdot 0 \mathrm{ng} / \mathrm{ml}\right)$, and the Scatchard analysis showed a single class of high affinity binding sites with 
Table 1 IGF-I-receptor mRNA levels and clinical characteristics of evaluated normal adrenomedullary tissue and pheochromocytomas

\section{Diagnosis}

Patient

sex/age

$\delta / 58$

$\bigcirc / 72$

$\$ / 72$

$+/ 61$

$+/ 70$

$+/ 55$

ऽ/58

$\delta / 51$

$\delta / 68$

$5 / 66$

\%/64

$\circ / 71$

\%/69

$\delta / 49$

$\delta / 51$

$\delta / 33$

$8 / 29$

$+/ 34$

$\delta / 41$

$0 / 38$

/48

$\$ / 52$

$+/ 44$

$+/ 56$

ऽ/36

$+/ 30$

$+/ 35$

$+/ 62$

$+/ 58$

\section{Normal adrenal medulla}

Normal adrenal medulla

Normal adrenal medulla

Normal adrenal medulla

Normal adrenal medulla

Normal adrenal medulla

Normal adrenal medulla

Normal adrenal medulla

Normal adrenal medulla

Normal adrenal medulla

Normal adrenal medulla

Normal adrenal medulla

Normal adrenal medulla

Pheochromocytoma

Pheochromocytoma

Pheochromocytoma

Pheochromocytoma

Pheochromocytoma

Pheochromocytoma

Pheochromocytoma

Pheochromocytoma

Pheochromocytoma

Pheochromocytoma

Pheochromocytoma

Pheochromocytoma

Pheochromocytoma

Pheochromocytoma

Pheochromocytoma

Pheochromocytoma
Catecholamine secretion $(\mu \mathrm{g} / 24 \mathrm{~h})$

\begin{tabular}{ll}
\hline $\begin{array}{l}\text { Adrenaline } \\
\text { (Norm: 4-20 } \mu \mathrm{g} / \mathrm{d})\end{array}$ & $\begin{array}{l}\text { Noradrenaline } \\
(\text { Norm: 20-105 } \mu \mathrm{g} / \mathrm{d})\end{array}$ \\
\hline
\end{tabular}

IGF-IR-mRNA

$\times 10^{3}$ molecules/ug RNA

$\begin{array}{cr} & - \\ - & - \\ - & - \\ - & - \\ - & - \\ - & - \\ - & - \\ - & - \\ - & - \\ \text { Sporadic/benign } & 246.2 \\ \text { Sporadic/benign } & 187.2 \\ \text { MEN Ila/benign } & 155.5 \\ \text { VHL/benign } & 187.6 \\ \text { MEN Ila/benign } & 88.3 \\ \text { Sporadic/benign } & 46.8 \\ \text { Sporadic/benign } & 286.4 \\ \text { Sporadic/benign } & 345.9 \\ \text { Sporadic/benign } & 172.5 \\ \text { Sporadic/benign } & 285.6 \\ \text { Sporadic/benign } & 455.6 \\ \text { Sporadic/benign } & 155.4 \\ \text { VHL/benign } & 187.2 \\ \text { VHL/benign } & 245.6 \\ \text { Sporadic/benign } & 99.4 \\ \text { Sporadic/malignant } & 286.5\end{array}$

Sporadic/malignant $\quad 286.5$

$\begin{array}{rr}- & 513 \\ - & 625 \\ - & 798 \\ - & 2622 \\ - & 2623 \\ - & 2620 \\ - & 2554 \\ - & 2953 \\ - & 2964 \\ - & 3648 \\ - & 3283 \\ - & 3762 \\ 688.1 & 7200 \\ 543.6 & 2303 \\ 2557.4 & 2850 \\ 1455.6 & 4446 \\ 1866.8 & 5130 \\ 546.7 & 5244 \\ 1433.1 & 5700 \\ 685.9 & 6042 \\ 571.6 & 6384 \\ 1479.1 & 6384 \\ 1885.3 & 6452 \\ 894.3 & 7068 \\ 3655.6 & 9120 \\ 1465.7 & 9918 \\ 1006.4 & 12540 \\ 3148.6 & 14250 \\ & 20520\end{array}$

513

798

2622

2623

2953

2964

3283

3762

7200

$(303$

4446

5130

5244

6042

6384

6452

7068

9918

2540

20520

MEN Ila, multiple endocrine neoplasia Ila; VHL, von Hippel-Lindau.

normal binding kinetics in all examined pheochromocytomas $\left(K_{\mathrm{d}} 0.20 \pm 0.09 \mathrm{nmol} / \mathrm{l}\right)$, indicating overexpression of normal intact human IGF-IR in human pheochromocytomas. A representative comparison of the Scatchard plots for a pair of normal adrenomedullary and pheochromocytoma tissue samples is shown in Fig. 3.

\section{Discussion}

The presence of IGF-I receptors in pheochromocytoma cells has already been described in samples from human adrenal tumors (Kamino et al. 1991) as well as in PC12 cells, a cell line derived from rat pheochromocytoma (Dahmer et al. 1989). However, information about the IGF-I receptor expression in human pheochromocytoma cells in comparison with normal adrenomedullary tissue has not been available to date.
The present study is the first to report a significant overexpression of the IGF-I receptor in human pheochromocytomas. The analysis of tissue samples from human pheochromocytomas via RT-PCR showed markedly elevated levels of IGF-IR mRNA in pheochromocytoma cells compared with normal adult adrenal medulla. In up to $85 \%$ of all pheochromocytomas examined, a more than twofold higher expression of IGF-IR mRNA was observed, with a mean $2 \cdot 5$-fold overexpression. A comparable IGF-IR overexpression was also present at the protein level as confirmed by Scatchard analysis. The binding kinetics of the IGF-I receptors in pheochromocytoma cells were similar to those observed in normal adrenomedullary tissue, suggesting that the abundant IGF-I receptors in pheochromocytomas are functionally intact.

In PG12 cells, IGF-I receptors have been shown to be important for the stimulation of cell replication (Dahmer et al. 1989) and the IGFs are potent mitogens stimulating 
A

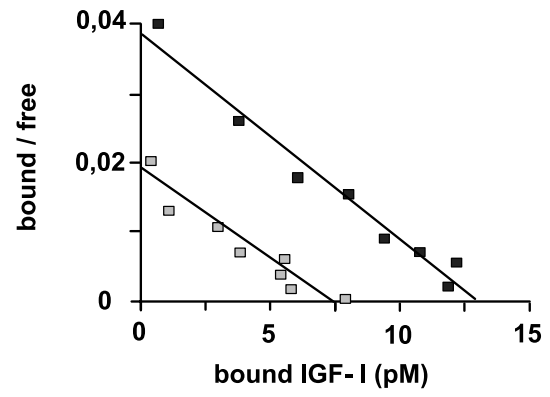

$\square$ adrenal medulla

pheochromocytoma

\begin{tabular}{|c|c|c|}
\hline & adrenal medulla & pheochromocytoma \\
\hline $\begin{array}{l}\mathrm{Kd} \\
\text { (nmol/l) }\end{array}$ & $0.32 \pm 0.1$ & $0.2 \pm 0.09$ \\
\hline $\begin{array}{l}\mathrm{ED}_{50} \\
(\mathrm{ng} / \mathrm{ml})\end{array}$ & $6.1 \pm 2.0$ & $5.6 \pm 1.0$ \\
\hline $\begin{array}{l}\text { Receptor - } \\
\text { number } \\
\text { (nmol/kg } \\
\text { protein) }\end{array}$ & $2.43 \pm 1.2$ & $5.8 \pm 0.5^{*}$ \\
\hline
\end{tabular}

Figure 3 (A) Scatchard analysis of the competitive ${ }^{125}$ |-IGF-I binding data to human pheochromocytomas (solid symbols) and normal adrenomedullary tissue (shaded symbols). Each point represents the mean of duplicate determinations of a single representative experiment. (B) Binding characteristics of the IGF-IR in human pheochromocytomas and normal human adrenomedullary tissue. Results are means \pm S.E.M. of 5 (normal) and 17 (pheochromocytomas) independently performed binding experiments. ${ }^{*}=P<0.05$.

cell proliferation three times over basal. IGF-I was 10 times more potent in stimulating DNA synthesis than IGF-II, suggesting that these effects are mediated by the IGF-IR (Dahmer \& Perlman 1988, Nielsen \& Gammeltoft 1988). Moreover, binding affinities to the IGF-IR correlate directly with the ability of IGF-I and IGF-II to completely prevent apoptosis in PG12 cells (Forbes et al. 2002). In these cells, promotion of cell growth and proliferation by IGF-I is exerted by the ERK pathway (Foncea et al. 1997), whereas for prevention of apoptosis the phosphatidylinositol 3-kinase pathway is involved (Kulik et al. 1997).

Overexpression of the IGF-I receptor is not a phenomenon confined to adrenal tumors. In common malignant tumors such as colorectal and gastric cancer as well as in prostate and breast cancer, a strong overexpression of the IGF-IR has been observed. It promotes ligand-dependent neoplastic transformation and there is a quantitative relationship between tumorigenesis and IGF-IR levels, while the absence of IGF-IR prevents malignant growth and transformation (Moschos \& Mantzoros 2002). Additionally, in these tumors a positive correlation between IGF-IR overexpression and malignant phenotype has been observed. The mechanisms responsible for enhanced IGF-IR expression in pheochromocytomas and other malignancies are still unclear. However, expression of the IGF-IR is regulated by a variety of factors, including tumor suppressor genes, transcription factors and other growth factors. In several different IGF-IR overexpressing malignant cell systems such as colorectal, gastric, and adrenocortical cancer as well as in osteosarcoma and hematopoetic cells, alterations of tumor suppressor genes and transcription factors important for IGF-IR regulation, such as p53 and Spl, have been demonstrated (Werner et al. 2000, Baserga et al. 2003). In normal cells, expression of wild-type p53 was shown to inhibit IGF-IR gene expression, whereas mutant p53 upregulates IGF-IR gene expression in several different tumors. In adrenocortical carcinomas, mutations within the conserved regions of p53 have been found in approximately $30 \%$ of malignant adrenocortical tumors, whereas mutations are rarely found in benign adrenocortical adenomas (Fottner et al. 2004). Similar results have been found in colorectal-cancer and osteosarcoma cells, suggesting a role for p53 in upregulating IGF-IR expression (Ohlsen et al. 1998, Durai et al. 2005). Additionally, the expression of the IGF-IR has been shown to be regulated by the transcription factor, Spl via specific binding sites within the IGF-IR promoter region. In human gastric cancer, overexpression of the IGF-IR strongly correlated with Spl expression and with an advanced tumor stage, increased lymph node metastasis and predicted a poor survival, whereas enforced down-regulation of Spl and IGF-IR expression suppressed growth and metastasis of gastric cancer in animal models (Wang et al. 2003, Jiang et al. 2004). Therefore, altered expression of the IGF-IR, one of the down-stream effectors of Spl, may play an important role in cancer growth and metastasis. Furthermore, the frequently observed elevated IGF-II concentration in malignancies overexpressing the IGF-IR might additionally contribute to the overexpression of IGF-I receptors in these tumors. In CaCo-2 human colon carcinoma cells, it has been shown that stable overexpression of IGF-II resulted in increased IGF-IR expression with increased proliferation and anchorage-independent growth (Hoeflich et al. 1996), and in colorectal carcinomas a positive correlation between the expression of IGF-II and IGF-I receptors has been reported (Weber et al. 2002).

The molecular mechanisms by which overexpression of the IGF-IR is induced in pheochromocytomaassociated hereditary syndromes like MEN or von Hippel-Lindau disease are still unclear. However, in 
renal carcinoma cells (RCG) wild-type von HippelLindau gene (VHL) has been shown to block protein kinase C-delta (PKC-delta), an important downstream signaling molecule of IGF-IR-mediated cell proliferation and transformation. In mutated VHL, this tumor suppressor function gets potentially lost. VHL has also been shown to regulate the protein expression levels of IGF-IR (Li et al. 1998, Datta et al. 2000). It is therefore tempting to speculate if alterations in PKC-deltamediated pathways are involved in the increased expression of IGF-IR in human pheochromocytoma cells.

Previous studies by our own group and by others have shown a critical role of the IGF system in either normal adrenocortical cells or in adrenocortical tumors (Weber et al. 1997, Boulle et al. 1998, Fottner et al. 1998, 2001). Several authors report the effects of high amounts of IGF-II in human adrenal pheochromocytomas on protein and mRNA levels (Hasselbacher et al. 1987, Gelato \& Vassalotti 1990) despite unaltered levels of IGF-I. Compared with normal adrenomedullary tissue, 20 times more immunoreactive IGF-II per gram of tissue was measured in samples from human pheochromocytomas. IGF-II seems to be secreted by pheochromocytoma cells in an autocrine or paracrine manner, supporting tumor growth locally, while the IGF-II serum levels remain unaltered (Gelato \& Vassalotti 1990). We speculate that the marked overexpression of the IGF receptor type I and IGF-II in human pheochromocytoma cells results in a state of constitutive growth stimulation in vivo. In malignant adrenocortical carcinomas, overexpression of IGF peptides (mainly IGF-II), receptors (IGF-IR) and binding proteins (IGFBP-2) has been observed. In contrast, expression of IGF-I peptides and receptors appears to be unaltered in adrenocortical hyperplasia and adenomas. Adrenocortical carcinoma, a rare, highly malignant subtype of cancer, showed a 3- to 4-fold increase in IGF-IR expression and a 10- to 100-fold increase in IGF-II expression (Liu 1995, Weber et al. 1997). Functionally, an autocrine stimulatory loop contributing to adrenocortical tumorigenesis may underlie this specific expression pattern. A similar pattern of high IGF-II and concomitant IGF-IR overexpression has previously been reported for neuroblastoma cells (Leventhal et al. 1990) and more recently by our group in human colon carcinomas (Weber et al. 2002). The exact role of the frequently observed overexpression of IGF-binding proteins in parallel with the overexpression of the IGF-I receptor and IGF ligands is still unclear and although high concentrations, especially of IGFBP-2, are a frequent finding in a variety of malignant tumors such as adrenocortical, prostate, breast and colonic cancer, the functional significance remains unclear. Since IGFBPs modulate cellular bioavailability of IGFs and, in addition, have been shown to directly regulate tumor growth and invasion (Hoeflich et al. 2001), it is likely that overxpression of IGFBPs in cancer is not merely an epiphenomenon. Similar to these results, one study also reports a higher expression of IGFBP-2 in human pheochromocytomas in comparison with normal adrenal glands (Ilvesmäki et al. 1998) and recently published data show that IGFBP-2 plays a critical role in neuroblastoma cell proliferation, migration and invasion, thus pointing to an important role of IGFBP-2 in chromaffin cell tumors (Russo et al. 2005). However, additional studies are necessary to further characterize the role of IGFBPs in human pheochromocytomas.

Since overexpression of IGF-IR promotes neoplastic growth (Kaleko et al. 1990) and absence of the IGF-IR has been shown to prevent malignant transformation (Rubin \& Baserga 1995), it is tempting to speculate about a possible role of IGF-IR in malignant transformation of human pheochromocytoma cells. It would be interesting to elucidate if the degree of IGF-IR expression in pheochromocytomas correlates with the tumor size and a more malignant phenotype, as has previously been reported for other malignant tumors such as colorectal, gastric and mammary cancers and in adrenocortical carcinomas (Fottner et al. 2004, Foulstone et al. 2005). In the present study, no correlation between clinical characteristics, such as catecholamine secretion or tumor size could be found (Table 1). In contrast, in the subsequent studies, one malignant pheochromocytoma (characterized by the presence of distant metastases) has been examined, and this showed the strongest overexpression of IGF-IR of all investigated pheochromocytomas. This could support the hypothesis mentioned above. However, due to the small number of tumors examined in this study, at this point there is no clear evidence for a correlation between the degree of IGF-IR overexpression and other clinical characteristics and a more malignant phenotype.

Further investigation is needed to clarify if the observed overexpression of IGF-IR is part of a functionally relevant mechanism promoting tumor growth in human pheochromocytoma and possibly promoting malignant transformation of these cells. If so, the IGF system might be an interesting focus for new therapeutic approaches.

\section{Acknowledgements}

This work is part of the doctoral thesis of S K.

\section{Funding}

This work was supported by a DFG Grant WE 1356/4-2 to M M W. The authors declare that there is no conflict of interest that would prejudice the impartiality of this scientific work. 


\section{References}

Alms WJ, Braun-Elwert L, James SP, Yurovsky VV \& White B 1996 Simultaneous quantitation of cytokine mRNAs by reverse transcription-polymerase chain reaction using multiple internal standard cRNAs. Diagnostic and Molecular Pathology 5 88-97.

Baserga R, Peruzzi F \& Reiss R 2003 The IGF-I receptor in cancer biology. International fournal of Cancer 107 873-877.

Becker-Andre M \& Hahlbrook K 1989 Absolute mRNA quantification using the polymerase chain reaction (PCR). A novel approach by a PCR aided transcript titration assay (PATTY). Nucleic Acids Research 17 9437-9446.

Boulle N, Logie A, Gicquel C, Perin L \& Le Bouc Y 1998 Increased levels of insulin-like growth factor II (IGF-II) and IGF-binding protein-2 are associated with malignancy in sporadic adrenocortical tumors. Fournal of Clinical Endocrinology and Metabolism 83 1713-1720.

Chomczynski P \& Sacchi N 1987 Single-step method of RNA isolation by acid guanidinium thiocyanate-phenol-chloroform extraction. Annals of Biochemistry 162 156-159.

Dahmer MK \& Perlman RL 1988 Insulin and insulin-like growth factors stimulate desoxyribonucleic acid synthesis in PG12 pheochromocytoma cells. Endocrinology 122 2109-2113.

Dahmer MK, Ji L \& Perlman RL 1989 Characterisation of insulinlike growth factors-I receptors in PG12 pheochromocytoma cells and bovine adrenal medulla. Fournal of Neurochemistry 53 1036-1042.

Dahmer MK, Hart PM \& Perlman RL 1990 Studies on the effect of insulin-like growth factor I on catecholamine secretion from chromaffin cells. Fournal of Neurochemistry 54 931-936.

Datta K, Nambudripad R, Pal S, Zhou M, Cohen HT \& Mukhopadhyay D 2000 Inhibition of insulin-like growth factorI-mediated cell signaling by the von Hippel-Lindau gene product in renal cancer. Fournal of Biological Chemistry 275 20700-20706.

Durai R, Yang W, Gupta S, Seifalian AM \& Winslet MC 2005 The role of the insulin-like growth factor system in colorectal cancer: review of current knowledge. International Fournal of Colorectal Disease 20 203-220.

Foncea R, Andersson M, Ketterman A, Blakesley V, Sapag-Hagar M, Sugden PH, Le Roith D \& Lavandero S 1997 Insulin-like growth factor-I rapidly activates multiple signal transduction pathways in cultured rat cardiac myocytes. Fournal of Biological Chemistry 272 19115-19124.

Forbes BE, Hartfield PJ, McNeil KA, Surinya KH, Milner SJ, Cosgrove LJ \& Wallace JC 2002 Characteristics of binding of insulin-like growth factor (IGF)-I and IGF-II analogues to the type 1 IGF receptor determined by BIAcore analysis. European fournal of Biochemistry 269 961-968.

Fottner C, Engelhardt D \& Weber MM 1998 Regulation of steroidogenesis by insulin-like growth factors (IGFs) in adult human adrenocortical cells: IGF-I, and more potently IGF-II, preferentially enhance androgen biosynthesis through interaction with the IGF-I receptor and IGF-binding proteins. Fournal of Endocrinology 158 409-417.

Fottner C, Elmlinger M, Engelhardt D \& Weber MM 2001 Identification and characterization of insulin-like growth factor (IGF) binding protein expression and secretion by adult human adrenocortical cells: differential regulation by IGFs and adrenocorticotrophin. Fournal of Endocrinology 168 465-474.

Fottner C, Höflich A, Wolf E \& Weber MM 2004 Role of the insulin-like growth factor system in adrenocortical growth control and carcinogenesis. Hormone and Metabolic Research 36 397-405.

Foulstone E, Prince S, Zaccheo O, Burns JL, Harper J, Jacobs C, Church D \& Hassan AB 2005 Insulin-like growth factor ligands, receptors, and binding proteins in cancer. Fournal of Pathology $205145-153$.
Frödin M \& Gammeltoft S 1994 Insulin-like growth factors act synergistically with basic fibroblast growth and nerve growth factor to promote chromaffin cell proliferation. PNAS 91 1771-1775.

Gelato MC \& Vassalotti J 1990 Insulin-like growth factor II: possible local growth factor in pheochromocytoma. Fournal of Clinical Endocrinology and Metabolism 71 1168-1174.

Gilliland G, Perrin S, Blanchard K \& Bunn HF 1990 Analysis of cytokine mRNA and DNA: detection and quantitation by competitive polymerase chain reaction. PNAS 87 2725-2729.

Haselbacher GK, Irminger JC, Zapf J, Ziegler WH \& Humbel RE 1987 Insulin-like growth factor II in human adrenal pheochromocytomas and Wilms tumors: expression at the mRNA and protein level. PNAS 84 1104-1106.

Hoeflich A, Yang Y \& Rascher W 1996 Coordinate expression of insulin-like growth factor II (IGF-II) and IGF-II/mannose-6phosphate receptor mRNA during differentiation of human colon carcinoma cells (caco-2). European Foumal of Endocrinology $13549-59$

Hoeflich A, Reisinger E, Lahm H, Kiess W, Blum WF, Kolb HJ, Weber MM \& Wolf E 2001 Insulin-like growth factor binding protein 2 in tumorigenesis: protector or promoter? Cancer Research 61 $8601-8610$

Hwang O \& Choi HJ 1996 Induction of gene expression of the catecholamine-synthesizing enzymes by insulin-like growth factor I. Fournal of Neurochemistry 65 1988-1996.

Ilvesmäki V, Kahri AI, Miettinen PJ \& Voutilainen R 1993 Insulin-like growth factors (IGFs) and their receptors in adrenal tumors: high IGF-II expression in functional adrenocortical carcinomas. Fournal of Clinical Endocrinology and Metabolism $77852-858$.

Ilvesmäki V, Liu J, Heikkilä A, Kahri AI \& Voutilainen R 1998 Expression of insulin-like growth factor binding protein 1-6 genes in adrenocortical tumors and pheochromocytomas. Hormone and Metabolic Research 30 619-623.

Jiang X, Wang L, Gong W, Wei D, Le X, Yao J, Ajani J, Abbruzzese JL, Huang S \& Xie K 2004 A high expression of insulin-like growth factor I receptor is associated with increased expression of transcription factor $\mathrm{Spl}$ and regional lymph node metastasis of human gastric cancer. Clinical and Experimental Metastasis 21 755-764.

Kaleko M, Rutter WJ \& Miller AD 1990 Overexpression of the human insulin-like growth factor I promotes ligand-dependent neoplastic transformation. Molecular Cell Biology $10464-473$.

Kamino T, Shigematsu K, Kawai K \& Tsuchiyama H 1991 Immunoreactivity and receptor expression of insulin-like growth factor I and insulin in human adrenal tumors. American fournal of Pathology 138 83-91.

Kulik G, Klippel A \& Weber MJ 1997 Antiapoptotic signaling by the insulin-like growth factor I receptor phosphatidylinositol 3-kinase. Molecular and Cellular Biology 17 1595-1606.

Kutoh E, Boss O, Levasseur M \& Giacobino JP 1998 Quantification of the full length leptin receptor (OB-Rb) in human brown and white adipose tissue. Life Sciences $\mathbf{6 2} 445-451$.

Leventhal PS, Randolph AE, Vesbit TE, Schenone A, Windebank AJ \& Feldmann EL 1990 Insulin-like growth factor as a paracrine growth factor in human neuroblastoma cells. Experimental Cell Research 221 179-186.

Li W, Jiang YX, Zhang J, Soon L, Flechner L, Kapoor V, Pierce JH \& Wang LH 1998 Protein kinase C-delta is an important signaling molecule in insulin-like growth factor I receptormediated cell transformation. Molecular and Cellular Biology 18 5888-5898.

Menouny M, Binoux M \& Babajko S 1997 Role of insulin.like growth factor binding protein-2 and its limited proteolysis in neuroblastoma cell proliferation: modulation by transforming growth factor-beta and retinoic acid. Endocrinology 138 683-690. 
Moschos SJ \& Mantzoros CS 2002 The role of the IGF system in cancer: from basic to clinical studies and clinical applications. Oncology 63 317-332.

Nielsen FC \& Gammeltoft S 1988 Insulin-like growth factors are mitogens for rat pheochromocytoma PC 12 cells. Biochemical and Biophysical Research Communications 154 1018-1023.

Ohlsson C, Kley N, Werner H \& LeRoith D 1998 p53 regulates insulin-like growth factor-I (IGF-I) receptor expression and IGF-I induced tyrosine phosphorylation in an osteosarcoma cell line: interaction with p53 and Spl. Endocrinology 139 1101-1107.

Rubin R \& Baserga R 1995 Insulin-like growth factor I receptor. Its role in cell proliferation, apoptosis and tumorigenicity. Laboratory Investigations 73 311-331.

Russo VC, Schutt BS, Andaloro E, Ymer SI, Hoeflich A, Ranke MB, Bach LA \& Werther GA 2005 Insulin-like growth factor binding protein-2 binding to extracellular matrix plays a critical role in neuroblastoma cell proliferation, migration and invasion. Endocrinology 146 4445-4455.

Scatchard G 1949 The attraction of proteins for small molecules and ions. Annals of the Nerw York Academy of Sciences 51 660-672.

Singleton JR, Randolph AE \& Feldman EL 1996 Insulin-like growth factor I receptor prevents apoptosis and enhances neuroblastoma tumorigenesis. Cancer Research 56 4522-4529.

Sullivan KA, Castle VP, Hanash SM \& Feldmann EL 1995 Insulin-like growth factor II in the pathogenesis of human neuroblastoma. American Fournal of Pathology 147 1790-1798.

Ullrich A, Gray A, Tam AW, Yang-Feng T, Tsubokawa M, Collins C, Henzel W, Le Bon T, Kathuria S, Chen E et al. 1986
Insulin-like growth factor I receptor primary structure: comparison with insulin receptor suggests structural determinants that define functional specifity. EMBO fournal 5 2503-2512.

Wang L, Wei D \& Huang S 2003 Transcription factor Sp1 expression is a significant predictor of survival in human gastric cancer. Clinical Cancer Research 9 6371-6380.

Weber MM, Auernhammer C, Kiese W \& Engelhardt D 1997 Insulin-like growth factor receptors in normal and tumorous adult human adrenocortical glands. European Fournal of Endocrinology 139 296-303.

Weber MM, Fottner C, Liu SB, Jung MC, Engelhardt D \& Baretton GB 2002 Overexpression of the insulin-like growth factor I receptor in human colon carcinomas. Cancer 95 2086-2095.

Werner H, Shalita-Chesner M, Abramovitch S, Idelman G, Shaharabani-Gargir L \& Glaser T 2000 Regulation of the insulin-like growth factor-I receptor gene by oncogenes and anti-oncogenes: implications in human cancer. Molecular Genetics and Metabolism 71 315-320.

Zhang W, Thorton WH \& MacDonald RS 1998 Insulin-like growth factor-I and -II receptor expression in rat colon mucosa is affected by dietary lipid intake. Fournal of Nutrition 182 158-165.

Zumkeller W \& Schwab M 1999 Insulin-like growth factor system in neuroblastoma tumorigenesis and apoptosis: potential diagnostic and therapeutic perspectives. Hormone and Metabolic Research 31 138-141.

Received in final form 29 December 2005 Accepted 17 January 2006 